\title{
Determination of Widal Baseline Titre among Healthy Adult Individuals in Tumkur, India
}

\author{
S.C. Chandrashekar and M. Sudeep Kumar* \\ Department of Microbiology, Sri Siddhartha Medical College Tumkur-572107, India \\ *Corresponding author
}

\begin{tabular}{|l|}
\hline Ke y w or d s \\
$\begin{array}{l}\text { Enteric fever, Widal } \\
\text { test, Baseline titre }\end{array}$ \\
\hline Article Info \\
$\begin{array}{l}\text { Accepted: } \\
\text { 10 January } 2018 \\
\text { Available Online: } \\
\text { 10 February } 2018\end{array}$ \\
\hline
\end{tabular}

\section{A B S T R A C T}

Typhoid fever continues to be a global health problem, with an estimated 12 to 33 million cases occurring worldwide each year. India is an endemic country; sera of particular healthy individuals contain antibodies capable of reacting to a variable titre in Widal test due to previous stimuli. It is therefore, important to establish the antibody level in the normal population by "Widal baseline titre" in a particular locality. The serum samples are processed by Widal tube agglutination test to find out the baseline Widal titre. In the 500 samples 210 samples were positive for agglutinins to Salmonella typhi, paratyphi-A and paratyphi-B. In 210 positive samples, $166(33.2 \%)$ were positive for ' $O$ ' agglutinin and $184(36.8 \%)$ were positive for ' $\mathrm{H}$ ' agglutinins for. For paratyphi ' $\mathrm{AH}$ ' agglutinin is $21(4.2 \%)$ and for paratyphi 'BH' agglutinin is $16(3.2 \%)$. Widal baseline titre helps in diagnosis of enteric fever as a single diagnostic tool in particular geographical area. The significant titre of the 'O' agglutinins and the ' $\mathrm{H}$ ' agglutinins of Salmonella typhi was $\geq 1$ : 80. While the significant titre of the ' $H$ ' agglutinins of Salmonella paratyphi $A$ was $\geq 1$ : 80 and ' $\mathrm{H}$ ' agglutinins of Salmonella paratyphi $B$ was $\geq 1: 40$.

\section{Introduction}

Typhoid fever continues to be a global health problem, with an estimated 12 to 33 million cases occurring worldwide each year. Incidence of typhoid fever has been estimated approximately 17 million cases with 6,00,000 associated deaths occurring annually (Gasem et al., 2001). A very similar but often less severe disease is caused by $S$. paratyphi $A, B$ and sometimes $C$. S. typhi, a highly adapted human-specific pathogen that evolved about 50,000 years ago, has remarkable mechanisms for persistence in its host (Pegues et al., 2005). Some Salmonella serotypes, such as S. typhi,
$S$. paratyphi and $S$. sendai are highly adapted to humans Salmonella typhi and have no other known natural hosts. The wide spread distribution of Salmonella in the environment, their increasing prevalence in the global food chain and their virulence and adaptability result in enormous medical, public health and economic impact worldwide (Old and Threlfal).

Salmonellosis including enteric fever has been effectively controlled in many developed countries. But in the developing countries like India, it continues to manifest as gastroenteritis associated with fever and sometimes 
leading to sepsis. Failure to implement or delay in starting effective treatment is associated with high mortality (20\%). Timely and effective treatment reduces the mortality rate to as low as 1\% (Manchanda et al., 2006).

Humans are the only natural host and reservoir for S. typhi. The pathogen can survive for days in groundwater, pond water or seawater, and for months in contaminated eggs and frozen oysters. The infectious dose is between 1000 and 1 million organisms given orally (Manchanda et al., 2006). The infection is transmitted by ingestion of food or water contaminated with faeces. Established risk factors are contaminated water supply, ice cream flavoured iced drinks or food from street vendors, and raw fruit and vegetables grown in fields fertilised with sewage. Other factors include a history of contact with other patients before illness, poor personal hygiene, poor housing, and past evidence of infection with Helicobacter pylori postulated to be due to decreased gastric acid (Black et al., 1985; Bhan et al., 2002).

Widal test detects agglutinating antibodies against the $\mathrm{O}$ and $\mathrm{H}$ antigens of S.typhi and $\mathrm{H}$ antigens of $S$. Paratyphi $A$ and $B$. Widal test becomes positive at end of the first week and peak by third week of disease. Antibodies against the $\mathrm{O}$ antigen are predominantly $\operatorname{IgM}$, rise early in the illness and disappear early. $\mathrm{H}$ antigens are flagellar antigens of $S$. typhi. $S$. paratyphi $A$ and $B$, begin to appear towards the end of the first week, increases to a maximum during 3rd week, and persist for month or years afterwards. Usually $\mathrm{O}$ antibodies appear on day 6-8 and $\mathrm{H}$ antibodies on days 10-12 after the onset of the disease. The test can be done in tubes or on slides (Old, 2006).

India is an endemic country; sera of particular healthy individuals contain antibodies capable of reacting to a variable titre in Widal test due to previous stimuli. It is therefore, important to establish the antibody level in the normal population by "Widal baseline titre" in a particular locality, in order to determine a threshold above which the antibody titre is considered significant (Pang, 1989). Therefore Widal baseline titre for anti-O and anti-H for Salmonella typhi and anti-H for paratyphi-A and paratyphi-Bare important. In India most patients present late to the hospital and require immediate diagnosis and specific treatment and often a single serum sample is relayed upon instead of paired serum samples. In these case high titre of anti-O and anti-H should be considered presumptive diagnosis for typhoid fever (Punia et al., 2003)

For the first 24 hours, diagnosis of enteric fever, blood culture technique is most widely used, but unfortunately the reports are not available for 24 to $48 \mathrm{hrs}$. Widal test is the second most widely used test after blood culture. So it is more important to know the baseline Widal titre in this area.

\section{Materials and Methods}

This was a cross-sectional study conducted at Department of microbiology, Sri Siddhartha Medical College, Tumkur, Karnataka. The study protocol was approved by the ethical committee of the Institution. A total of 500 serum samples collected from an individual in whom enteric fever and malaria were ruled out. All individuals who previously vaccinated against typhoid fever and those who were previously diagnosed with typhoid fever or those who gave a history of fever in past three months were excluded from the study.

For widal test about $5 \mathrm{ml}$ of venous blood sample was collected from each individuals, left to clot for 15 minutes at room temperature. The sera were separated by using micropipette. The separated sera were properly labeled and stored in $2-8^{0} \mathrm{C}$ for not 
more than seven days. The commercially available Widal tube agglutination test kits from span diagnostics were used. The tube agglutination test was carried out by using $0.5 \mathrm{ml}$ of two folded serially diluted sera (from $1: 20$ to $1: 320$ ). For this serum an equal amount of antigen were added and tubes were incubated over night at $37^{\circ} \mathrm{C}$ in water bath. The results were interpreted and analyzed as per standard guidelines (Freeman, 2005).

The Widal tube test was done in two sets of test tubes were labelled 1-6 for $\mathrm{O}$ and $\mathrm{H}$ antibody detection. Tube 1 of the two sets was pipetted $1.9 \mathrm{ml}$ of isotonic saline. The remaining tubes (2-6) were put 1.0 millilitre of isotonic saline. To the tube number one in each row, $0.1 \mathrm{ml}$ of the serum sample to be tested was added and mixed well.

One millilitre of the diluted serum was transferred from the tube number one to the tube number two and this serial dilution was continued till tube number seven of each set. Tube number six in the two sets served as a saline control. The dilution of the serum sample achieved in each set was as Tube no. : 12345 and 6 (control) Dilutions: 1:20 1:40 1:80 1:160 1:320.

To all tubes 1-6 of each set, one drop of the respective Widal test antigen suspension $(\mathrm{O}$, $\mathrm{H})$ from the reagent vials was added and mixed well. The tubes were covered and incubated at $37 \mathrm{oC}$ overnight. The titre of the patient's serum using Widal test antigen suspension is the highest dilution of the serum sample that gives a visible agglutination. The sample which showed a titre of 1:160 or more was considered as clinically significant (Crump et al., 2004).

Data collected was entered in Microsoft excel 2007 and analysed using Epi Info 3.4.3. Descriptive statistics such as roportion, mean and SD were used.

\section{Results and Discussion}

A total of 500 samples were collected from apparently healthy individuals and were further subjected to widal tube agglutination test. The distribution of individuals according to age group and sex is given in Table 1 and 2 .

In the 500 samples 210 samples were positive for agglutinins to Salmonella typhi, paratyphiA and paratyphi-B. In 210 positive samples, $166(33.2 \%)$ were positive for ' $\mathrm{O}$ ' agglutinin and $184(36.8 \%)$ were positive for ' $\mathrm{H}$ ' agglutinins for Salmonella typhi. For paratyphi 'AH' agglutinin is 21(4.2\%) and for paratyphi ' $\mathrm{BH}$ ' agglutinin is $16(3.2 \%)$. Among 166 positive samples for ' $\mathrm{O}$ ' agglutinins, 33(6.6\%) appeared agglutination upto 1 in 20 titre, $108(21.6 \%)$ appeared agglutination upto 1 in 40 titre, 22(4.4\%) appeared agglutination upto 1 in 80 titre and $3(0.6 \%)$ appeared agglutination upto 1 in 160 titre. In 184 positive samples for ' $\mathrm{H}$ ' agglutinins, 27(5.4\%) appeared agglutination upto 1 in 20 titre, $136(27.2 \%)$ appeared agglutination upto 1 in 40 titre, 18(3.6\%) appeared agglutination upto 1 in 80 titre and $3(0.6 \%)$ appeared agglutination upto 1 in 160 titre. In 21 positive samples for anti 'AH' agglutinins, 12(2.4\%) appeared agglutination upto 1 in 20 titre, 9(1.8\%) appeared agglutination upto 1 in 40 titre. In 16 positive samples for anti ' $\mathrm{BH}$ ' agglutinins, $12(2.4 \%)$ appeared agglutination upto 1 in 20 titre, $4(0.8 \%)$ appeared agglutination upto 1 in 40 titre (Table 3 ).

The Widal test is used to determine base line titre in this region for the diagnosis of enteric fever, no such study has been undertaken to determine base line titre. In this local region as for our knowledge concerned various studies have been conducted in India and across the world (Punia et al., 2003; Pokhrel et al., 2009; Peshattiwar, 2012), especially in developing countries. 
Table.1 Demographic distribution of individuals according to age group

\begin{tabular}{|r|c|c|}
\hline Age group & Frequency & Percentage \\
\hline $\mathbf{1 6 - 2 0}$ & 60 & 12 \\
\hline $\mathbf{2 1 - 3 0}$ & 282 & 56 \\
\hline $\mathbf{3 1 - 4 0}$ & 158 & 32 \\
\hline Total & 500 & 100 \\
\hline
\end{tabular}

Table.2 Demographic distribution of individuals according to Sex

\begin{tabular}{|c|c|c|}
\hline Sex & Frequency & Percentage \\
\hline Male & 362 & 72 \\
\hline Female & 138 & 28 \\
\hline Total & 500 & 100 \\
\hline
\end{tabular}

Table.3 Number and percentage of positive samples for agglutinins against various serotypes of Salmonella typhi and paratyphi $A \& B$

\begin{tabular}{|c|l|l|l|l|l|l|l|}
\hline Serotype & $\begin{array}{c}\text { Antib } \\
\text { ody } \\
\text { type }\end{array}$ & $\begin{array}{c}\text { No and } \\
\text { \% of +ve } \\
\text { samples }\end{array}$ & $\begin{array}{l}\text { Dilution } \\
(\mathbf{1} \text { in 20) }\end{array}$ & $\begin{array}{c}\text { Dilution } \\
(\mathbf{1} \text { in 40) }\end{array}$ & $\begin{array}{c}\text { Dilution } \\
(\mathbf{1} \text { in 80) }\end{array}$ & $\begin{array}{c}\text { Dilution } \\
\text { (1 in } \\
\mathbf{1 6 0})\end{array}$ & $\begin{array}{c}\text { Dilution (1 } \\
\text { in 320) }\end{array}$ \\
\hline S typhi & $\begin{array}{l}\text { Anti- } \\
\text { TO }\end{array}$ & $166(33.2)$ & $33(6.6)$ & $108(21.6)$ & $22(4.4)$ & $3(0.6)$ & NIL \\
\hline S typhi & $\begin{array}{l}\text { Anti- } \\
\text { TH }\end{array}$ & $184(36.8)$ & $27(5.4)$ & $136(27.2)$ & $18(3.6)$ & $3(0.6)$ & NIL \\
\hline $\begin{array}{c}\text { S paratyphi - } \\
\text { A }\end{array}$ & $\begin{array}{l}\text { Anti- } \\
\text { AH }\end{array}$ & $21(4.2)$ & $12(2.4)$ & $9(1.8)$ & NIL & NIL & NIL \\
\hline $\begin{array}{c}\text { S paratyphi - } \\
\text { B }\end{array}$ & $\begin{array}{l}\text { Anti- } \\
\text { BH }\end{array}$ & $16(3.2)$ & $12(2.4)$ & $4(0.8)$ & NIL & NIL & NIL \\
\hline
\end{tabular}

In the study conducted by Sunil Sonu Hatkar et al., (2016) A total of 340 blood samples were collected from healthy individuals and were further subjected to widal tube agglutination test. The result shows that the cutoff value for 'TO', 'TH', 'AH', and 'BH' were 1 in 40,1 in 80,1 in 40 and 1 in 20 . This is almost similar to our study.

In the study carried out by (Jeyakumari et al., 2015). In a total 500 blood samples, out of which 300 samples were collected from healthy blood donors, 200 samples were from patients who reported to various serological test except for widal. The significant titre for
'TO' is more than or equal to 1 in 160 , ' $\mathrm{TH}$ ' is more than equal to 1 in 160 , ' $\mathrm{AH}$ ' is more than or equal to 1 in 80 and ' $\mathrm{BH}$ ' is more than or equal to 1 in 40 . Comparing with our study these values are little bit high.

In another study conducted by (Nidhi Sharma et al., 2017) they found that a total of 170 blood samples were collected and further subjected to widal tube agglutination test. The result shows that cutoff value for 'TO', 'TH', 'AH', and ' $\mathrm{BH}$ ' were 1 in 40, 1 in 40, 1 in 40 and 1 in 20 . These results which were accordance with titre observed in our study. 
In our present study, shows baseline antibody for Salmonella typhi 'O' is less than or equal to 1 in 40, for Salmonella typhi ' $\mathrm{H}$ ' is $\leq 1$ in 40 , for Salmonella paratyphi 'A' is $\leq 1$ in 40 and for Salmonella paratyphi 'B' is $\leq 1$ in 20. So the significant titre for Salmonella typhi ' $\mathrm{O}$ ' is $\leq 1$ in 80 , for Salmonella typhi ' $\mathrm{H}$ ' is $\leq 1$ in 80 , for Salmonella paratyphi ' $A$ ' is $\leq 1$ in 80 and for Salmonella paratyphi 'B' is $\leq 1$ in 40 .

Baseline Widal titres vary from region to to region and with time to time. It is essential to know the levels of seroprevalence of the community to interpret the results. Widal baseline titre helps in diagnosis of enteric fever as a single diagnostic tool in particular geographical area. Our study shows that significant titre of the ' $\mathrm{O}$ ' agglutinins and the ' $H$ ' agglutinins of Salmonella typhi was $\geq 1$ : 80. While the significant titre of the ' $\mathrm{H}$ ' agglutinins of Salmonella paratyphi $A$ was $\geq$ 1: 80 and ' $\mathrm{H}$ ' agglutinins of Salmonella paratyphi $B$ was $\geq 1$ : 40 .

\section{References}

Gasem M.H., Dolmans W.M., Keuter M.M., Dokomoelanta R.R., Poor food hygiene and housing as risk factors for typhoid fever in Semarang, Indonesia. Trop Med Int Health 2001, 6; 484-490.

Pegues DA, Ohl ME, Miller SI. Salmonella species, including Salmonell typhi. In: Mandell GL, Bennett JE, Dolin R, editors. Principles and practice of infectious diseases. $6^{\text {th }}$ ed. Churchill Livingstone: New york; 2005. p. 263654

Old DC, and Threlfal EJ. Salmonella. In: Balows A, Duerden BI, editors. Topley and Wilson's microbiology and microbial infections. $9^{\text {th }}$ edn. Arnold: London. P.969-98

Manchanda V, Bhalla P, Sethi M, Sharma VK. Treatment of enteric fever in children on the basis of current trends of antimicrobial susceptibility of Salmonella enterica serovar Typhi and Paratyphi A. Indian Journal of Medical Microbiology 2006; 24(2): 101-6.

Manchanda V, Bhalla P, Sethi M, Sharma VK. Treatment of enteric fever in children on the basis of current trends of antimicrobial susceptibility of Salmonella enterica serovar Typhi and Paratyphi A. Indian Journal of Medical Microbiology 2006; 24(2): 101-6.

Black RE, Cisneros L, Levine MM, Banfi A, Lobos H, Rodriguez H. Case-control study to identify risk factors for paediatric endemic typhoid fever in Santiago, Chile. Bull World Health Organ 1985; 63: 899-904.

Bhan MK, Bahl R, Sazawal S et al., Association between Helicobacter pylori infection and increased risk of typhoid fever. J Infect Dis 2002; 186: 1857-60

Old DC. Salmonella. In: Collee JG, Fraser AG, Marimon BP, Simmons A. Salmonella. Editors: Mackie \& McCartney. Practical medical microbiology. 14th edition Edinburg: Churchill Livingstone, 2006: 385-404.

Pang T. False positive Widal test in non typhoidal Salmonella infection. Southeast Asian J Trop Med Pub Health; 1989, 20: 163-4

Punia J.N., RM Joshi, V Gupta, RK Arora., Determination of baseline Widal Titres from Chandigrah. Indian journal of medical microbiology 2003, 21 (2): 144

Freeman R. Bacterial immunoserology. In: Kaufmann SHE and Steward MW (eds) Topley and Wilson's Microbiology and Microbial infections, $10^{\text {th }}$ edn. Baltimore, MD: Edward Arnold Publishers, 2005, p.744

Crump, J. A., Luby, S. P. and Mintz, E. D. (2004).The global burden of typhoid fever. Bulletin of World Health 
Organization 82: 346-353.

Pokhrel BM, Karmacharya R, Mishra SK, Koirala J. Distribution of the antibody titre against Salmonella enterica among healthy individuals in Nepal. Ann Clin Microbiol Antimicrob. 2009; 8:1.

Peshattiwar P. Study of the baseline Widal titre amongst healthy individuals in Amlapuram, India. Journal of Clinical and Diagnostic Research. 2012 May (Suppl-1); 6(3):416-17.

Sunil Sonu Hatkar, Santosh Arvind Kotgire, Alka Ramchandrasingh Thakur Baseline widal titre among the healthy individuals: a study in and around
Badnapur, Marathwada region at Tertiary Care Hospital Indian J Microbiol Res 2016; 3(2): 162-165

Jeyakumari D, Jaberlin Sneha AJ, Gopal R. Study of the baseline widal titres among healthy individuals of rural population in Puducherry. Int $\mathrm{J}$ Med Res Health Sci. 2015; 4(2): 322-326

Nidhi Sharma, Kharibam Surpati Devi, Akhilesh P.S. Tomar. Study of the Baseline Widal Titres among Healthy Population in a Tertiary Care Hospital in Central India JMSCR Volume 05 Issue 04 April 2017

\section{How to cite this article:}

Chandrashekar, S.C. and Sudeepkumar, M. 2018. Determination of Widal Baseline Titre among Healthy Adult Individuals in Tumkur India. Int.J.Curr.Microbiol.App.Sci. 7(02): 957962. doi: https://doi.org/10.20546/ijcmas.2018.702.119 